\title{
THE NON-JURORS AND THE AUTHORITY FOR THEIR LATER HISTORY
}

\author{
THE STORY OF SOME HIDDEN MSS.
}

THE story of the Non-Jurors has never yet been fully told, although two historians of unquestioned learning have attempted the task: Thomas Lathbury in his History of the Nonjurors of 1845, Dr. Overton in his The Non-Jurors of 1902. Others, before and since, have written biographies of such leaders as Sancroft, Ken, Kettlewell, and Deacon, studies of great value for the general history; but that history, at least in its later chapters, has never been told completely. This failure has been due to no lack of energy nor of scholarship: it has been due to the simple fact that the necessary materials were to be found only in a jealously guarded collection of MSS. which was practically inaccessible until less than five years ago. It is the story of that collection of MSS., the search first for it and then for the history of its wanderings, that I propose to tell here. Let it be remembered that the Non-Jurors are no mere plaything for antiquaries. Their importance is recognized by theological and liturgical scholars in the United States, as some recent research work shows, and at home, as the prospect of Disestablishment draws nearer, English Churchfolk will see that useful lessons can be learnt from the experiences of the Non-Jurors two hundred years ago. It would seem to be true that when Establishment has been most valued the story of the Non-Jurors has been most neglected, but that as the connection with the State is less prized the Non-Jurors come into nearer view. That appears to be the explanation of the fact that it was long before any serious attempt was made to write their history.

About the beginning of the nineteenth century the NonJurors were absorbed into the ranks of the High Churchmen, but the High Churchmen seem to have been rather shy of the past of the newcomers. The reasons for that shyness are pretty clear. After the French Revolution High Churchmen had become Church-and-State men of the straitest school; Establishment was for them, as for most Latitudinarian Churchmen now, almost an article of the Creed. Many of them were half-consciously, as Dean Hutton has said of some Caroline High Churchmen, " incurably Erastian." And the Non-Jurors had stood for an entirely opposite view: rather than submit to State dictation they had endured poverty and persecution; "Establishment" had no charms for them. 
Further, many of the earlier and some of the later NonJurors had been Jacobites, opposed on principle to the rule of the House of Brunswick. But after the accession of George III. in 1760, and still more after excesses of the French Revolution, loyalty to the reigning House had risen almost to fever-heat among Churchmen. Therefore the High Churchmen of the first three decades of the nineteenth century were, with some distinguished exceptions, rather uncomfortable and shy when the Non-Jurors were mentioned.

That shyness can be discerned in the Memoir of John Bowdler, Esq., by his son Thomas, printed in 1824 (and published for general circulation a year later). John Bowdler had been brought up a Non-Juror; as a young man he had attended on his deathbed, in 1779, Robert Gordon, the last Bishop of the "Regular" line; yet his son is at pains to say as little as possible about the Non-Jurors, so that a reader who was not specially careful might go through the book without realizing the fact that John Bowdler had been a Non-Juror at all.

This rather unworthy silence was broken by the Oxford Movement. In January, 1837, a long article appeared in the British Critic on the Non-Jurors and their history. Its author was W. J. Copeland, and he followed it up by an article in the next year in the same magazine on Bishop Ken. Mr. Copeland's article is, I believe, the first attempt to tell the story of the Non-Jurors, and Copeland was one of those who were the backbone of the original Oxford Movement. In 1839 there followed a more noteworthy production, a useful little book, An Apology for the Doctrine of the Apostolical Succession, by the Rev. the Hon. A. P. Perceval, who is famous in Tractarian story. In one of the Appendixes to his book Mr. Perceval told with remarkable accuracy and conciseness the history of the Non-Jurors, and published for the first time a list of their bishops with dates of consecration. The book provoked some comment; it was denounced as "one of the most Jesuitical productions" of the "Oxford papists," but its most important result was a letter in the British Magazine for May, 1840. This letter, written from Trinity College, Cambridge, was signed " W.," an initial very evidently intended to reveal the then Master of Trinity, Dr. Christopher Wordsworth, the eminent Church historian. The letter corrected a few details in Mr. Perceval's account, and urged that a history of the Non-Jurors should be written. "Perhaps a more welltimed publication there could not be," it concluded, " than a history of the Non-Jurors." This letter was a valuable link in a chain of evidence to be mentioned later, for it expressed a hope that some information from " the Bowdler MSS." 
THE NON-JURORS AND THEIR LATER HISTORY 285

might soon be published. Its immediate result was that Mr. Perceval considerably expanded his Appendix on the NonJurors in the next edition of his book, in 1841, and possibly it fired Mr. Lathbury to write his History, published in 1845, but this is uncertain, since Mr. Lathbury (and Dr. Overton nearly sixty years later) missed the importance of some clues which the letter of " W." gave.

Two points in Perceval's account are worth noting; one, indeed, is of great importance. Firstly, Mr. Perceval wrote of the Non-Jurors in the deprecatory and apologetic strain characteristic of the older High Churchmen. The facts he puts on record, "painful and melancholy as they are, as records of the errors of high-minded and honourable men, will not be without their use, if they shall assist in convincing any person of the wretchedness of schism." Certainly this was not a very enthusiastic exordium to the romantic history of the Non-Jurors, but it exactly represented the view of the school in which Mr. Perceval had been bred.

The second point was far more important. For his facts Mr. Perceval had relied, he says, on his own collection of printed books and on information given by the Rev. T. Bowdler" and the Rev. H. H. Norris; he refers, indeed, to " the Bowdler MSS." as authorities of great importance. The two historians of the Non-Jurors, Mr. Lathbury and Dr. Overton, seem to have missed Mr. Perceval's modest abridgment of the story; had they known it, it would have saved them from some slips and it would have directed their attention to the authority on which the latter part of the story must rest-the "Bowdler MSS."

Both Mr. Perceval's living authorities, Mr. Norris and Mr. Bowdler, deserve a word of notice. Henry Handley Norris (1771-1850), familiarly known as "Norris of Hackney," is touchingly commemorated by his friend Archdeacon E. Churton in his Memoir of Joshua Watson. He was Prebendary of Llandaff and of St. Paul's, but steadily refused all other preferment and lavished his wealth upon the older Church societies (S.P.C.K. and S.P.G.) and upon such new ones as he helped to found. He was the leader of the older High Churchmen for a generation, the head of " the Clapton phalanx" as opposed to " the Clapham sect." He was keenly interested in the history of the Non-Jurors, and his own researches into it, chiefly connected with Bishop Cartwright and the later NonJurors at Manchester, are among the collections in the Bodleian Library at Oxford (MSS. Add. D. 30).

Mr. Norris was known in his day as "the last of the NonJurors," the late President of St. John's used to say, but the nickname came to him from his interest in their story rather 
than from his sympathy with Non-Juring theology. Thomas Bowdler (1782-1856) was, like Mr. Norris, a graduate of Cambridge and a Prebendary of St. Paul's. Much of his ministerial life, too, was spent near London, for in 1834 he became incumbent of Sydenham. Thomas Bowdler was, what Norris was not, keenly in sympathy with the Oxford Tractarians (though the Dictionary of National Biography strangely asserts that he "took an active part in opposing the Tractarian movement of 1840 "), and among his closest friends were W. J. Copeland and A.H.D. [Acland-] Troyte. Mr. Bowdler was by birth, if such a thing be possible, a Non-Juror, for his father, grandfather, and great-grandfather had all belonged to that body. Such were the two authorities who had helped Mr. Perceval with his story, and of the two Thomas Bowdler was by far the more important. For he was the owner of the "Bowdler MSS."

My own knowledge of that mysterious authority was due originally to a story which the late President of St. John's College, Oxford (Dr. James Bellamy, 1819-1909), used to tell of his predecessor, Dr. Philip Wynter, who died in 1871. Dr. Wynter, who has earned unenviable fame by his scandalous suspension of Dr. Pusey in 1843, was once greatly annoyed to hear a Fellow of the College declare that Dr. Richard Rawlinson (the famous antiquary, an alumnus and benefactor of St. John's) had been a Non-Juring Bishop. History, indeed, seems to have been no more Dr. Wynter's strong point than theology, for he promptly contradicted the statement. The Fellow, thus challenged, undertook to prove the fact, and obtained from a friend in London (who had many such documents, Dr. Bellamy used to say) a "Letter of Orders " issued by Rawlinson. This "Letter" having done its work of confuting Dr. Wynter, was deposited, so the President said, in the College Library.

There in 1903 and later I searched for it, but failed to find a trace of it, for it was entered in no catalogue and all knowledge of it seemed lost. But Dr. Bellamy was clear that it had been put there. At length, after many attempts, I discovered the document, or rather a dossier containing six documents, fast wedged at the back of a shelf of a cupboard in a writing-table. There was no Letter of Orders, but there was the far more valuable Instrument of Union which healed the division between the Usagers and Non-Usagers in 1732, and two letters about it of the same date both addressed to Dr. Brett, ${ }^{*}$ most learned of the later Non-Juring Bishops. Some five years later, in 1909, Dr. Hutton, the present Dean of Winchester, discovered the

* Dr. Brett was the son and successor of the Squire of Spring Grove near Wye in Kent. Originally admitted as pensioner to Queen's College, Cambridge, in 1683/4, he migrated to Corpus Christi College in 1688/9, and took his degree of LL.B. from that House. He became LL.D. in 1697. 
THE NON-JURORS AND THEIR LATER HISTORY 287

MSS. entirely independently; he realized their importance as I had not, and printed the three mentioned in the Athenceum of May 8, 1909. The Dean did not print, however, the three covering documents of the nineteenth century, which were two letters of May and June, 1856, from Thomas Bowdler to Mr. J. Hunter Reid, Fellow of St. John's, and a Memorandum by Mr. Reid, dated December 30, 1856, which stated that Mr. Bowdler had produced the papers " out of a very voluminous mass of Non-Juring correspondence obtained on account of the intimate relations of his family with the Non-Jurors." Here then were the "Bowdler MSS.," but the prospect opened only to close again, for Mr. Reid's paper added that "Mr. Bowdler deceased in November, 1856."

I made such enquiries as I could about the fate of the " voluminous mass," but I could get no clue, and I put aside further study of the Non-Jurors for a time. Some years later, in 1916, I was in Oxford for work at another subject, when on the day after my arrival the present Dean of Winchester told me that some Non-Jurors MSS. were for sale at a bookseller's and asked me to see them and report. I went immediately, and found twenty folio volumes, stoutly bound in half-calf, each volume lettered (by an odd misprint) " Papers of Ten (i.e., THE) Non-Jurors." The bookseller told me the price, a high one (three figures), but two American Universities had already offered it, and he thought that if the collection were broken up the autographs would fetch even more. I asked the favour of the refusal of the MSS. for a fortnight, and permission to examine some volumes at leisure, requests which were at once most courteously granted. Examination soon showed that the collection was that of the letters and papers of Dr. Thomas Brett, the Non-Juror Bishop who died on March 5, 1743/4. Helped by private subscriptions, the Curators of the Bodleian Library bought the collection within the fortnight allowed, and the twenty volumes passed into the Library in July, 1916. All that was then known of the history of the MSS. was that they had been bought by the bookseller on the sale of the library of Mr. T. W. Jackson, Fellow of Worcester College, who had died in 1914, and that Mr. Jackson had bought them from a dealer in London.

By chance, a few months later, a clue to the story of the papers came into my hands, for, reading the British Magazine for 1840, I stumbled upon the letter about the Non-Jurors written, as I believe, by Dr. Wordsworth which I have mentioned above. In that letter occurs the sentence "The Bowdler MSS. are, I believe, Dr. Brett's papers (Life of Bowdler)." Here was a clue indeed, for if it were true I had blundered by chance on 
the Bowdler MSS. which I had been hoping to find for thirteen years past, and incidentally I had found the key to the fortunes of the MSS. for a hundred years. The clue was perfectly good, unlike one that I followed later. Dr. Brett died in 1743/4, and was succeeded by his son Nicholas. John Bowdler was sent to be taught by Nicholas Brett, who at his death in $\mathbf{1 7 7 6}$ left him "all his pamphlets and papers, an honourable mark of the regard and good opinion which he entertained towards his pupil "(John Bowdler, p. 24, note). John Bowdler died in 1823 and was succeeded by his son Thomas already mentioned, and the evidence of Mr. Perceval's book in 1839 and the letters of 1856 which I had found at St. John's showed that Thomas Bowdler was in possession of the MSS. In fact, though I did not know it, Thomas Bowdler published three letters from the MSS. (on the differences between England and Rome) in 1850. But Thomas Bowdler had died on November 12, 1856, and here the story of the MSS stopped. How was it that no historian had had access to them for the sixty years which followed? I tried various paths to find the answer. Thomas Bowdler's heir, I found, was a nephew, his sister's son, a squire in Kent. By the kindly help of antiquaries I traced this family and got into touch with this gentleman's son; he was much interested in my search, but had never seen nor even heard of the twenty folios of Bowdler (i.e., Brett) MSS. Then, in that mine of information about the older High Churchmen, Archdeacon Churton's Memoir of Joshua Watson, I came across a hint, but a hint as mysterious and elusive as the Bowdler MSS. themselves. The Archdeacon wrote in 1861 of " a want of accuracy in the current statements" about the later Non-Jurors which might be remedied " by those who have the authentic records, lately in the hands of Thomas Bowdler" (ii. 54). This looked as though Archdeacon Churton knew the whereabouts of the MSS. in 1861. He did, as I found later.

Meanwhile I received, by the kindness of Mr. H. P. K. Skipton, a copy of his paper on The Non Jurors printed in the St.Paul's Ecclesiological Society's Transactions for 1917. I found there a statement that the Brett MSS. had, at one time, belonged to Bishop Jebb of Limerick. Bishop Jebb died in 1833, there was clear evidence that Mr. Bowdler had the papers in 1839, and it was exceedingly improbable that they had ever been out of his possession. However, I pursued this fresh path. The statement rested on a letter written by Mr. T. W. Jackson in 1910, and I am driven to the conclusion, with all respect to Mr. T. W. Jackson's memory, that he must have dreamt it. But following that side track led me to the true path, for Mr. Skipton sent me a letter from a distinguished antiquary who had seen the Brett MSS. when they were in 
THE NON-JURORS AND THEIR LATER HISTORY 289

private hands in Cornwall in 1886 . "They were collected," said this authority, "by an old parson called Copeland, who was particularly interested in the Usages controversy of the Non-Jurors." The road was clear now, for in "the old parson called Copeland" it was easy to recognize the well-known Tractarian and student of the Non-Jurors, William John Copeland (1804-1885), the close friend of Cardinal Newman and Dean Church. And Mr. Copeland's MSS. and papers happened to be in my possession, having been given me in 1917. I set to work to go through them. In the more than 230 as yet unpublished letters from Cardinal Newman to Copeland I found no allusion to the Non-Jurors. Then among some autographs I found the signature "T. Bowdler," cut off from a letter, and the scent grew keener, for clearly there was some connection between Copeland and Bowdler. Finally I came upon a packet of letters from Thomas Bowdler to Mr. Copeland, extending from 1841 to the end of Mr. Bowdler's life. There I found the clue. In a letter of December 14, 1854, Mr. Bowdler offered Copeland " all I have of Dr. Brett's letters and papers, for you have room in your house," and Copeland then had on loan "two volumes of the letters." Mr. Bowdler added: "I should naturally send them to W.M. Smith, Protestant representative of the family, as he calls himself, but he would, upon principle, lock them up and let no one see them." The generous gift was, it seems, declined at the time, but later came a letter endorsed by Copeland "Memoranda of Portraits of Hickes, Brett MSS., and works of Hickes and Brett," and the letter thus endorsed, written in a faltering hand, says, "My dear W. J. C., all other books of Hickes and Brett you will take for your own, and his portrait by Richardson, a pupil, I believe, of Hudson. There may be difficulty about MSS., especially the Vols. of Letters, but I wish you have (sic) them." Mr. Copeland preserved a copy of his reply accepting the gift. In it he said: "Should I make any use of them (i.e., the MSS.), it shall be guided by what I know to be your own judgment of the good and evil which might result from them, and when the time comes that I must do with them what you are doing, I shall regard them as a sacred trust to be delivered into safe hands." There was, it will be noticed, once again, something of the nervousness of the older High Churchmen about the Non-Jurors. Proof that Mr. Copeland actually had the Brett MSS. I found in a letter of his to Archdeacon Edward Churton written on December 27, 1859. He spoke there of " the voluminous letters of Dr. Brett which dear Mr. Bowdler gave me when he was dying," and in a later letter he referred to them again. But Mr. Copeland made no use of the MSS. himself; a MS. of Dr. Brett's on Suffragan Bishoprics printed in 1858, edited by 
the Rev. J. Fendall, Fellow of Jesus College, Cambridge, came from another source.

Mr. Copeland died on August 25, 1885, leaving everything to a nephew. His nephew's library was dispersed by auction in February, 1887 (the catalogue of the sale is in the British Museum), when the Brett MSS. were bought by Messrs. Bull and Auvache. The collection in its twenty folios is very well described on the front page of a catalogue of that firm offering it for sale (for eighty guineas) in 1888. From Messrs. Bull and Auvache Mr. T. W. Jackson bought the papers, but neither used them himself nor permitted others to use them, and they remained closely immured for another quarter of a century. In $1914 \mathrm{Mr}$. Jackson died, an Oxford bookseller bought the collection, and largely owing to his patriotism (for he was unwilling that it should go to America and kept it in hope of finding a purchaser in England), the collection passed, in 1916, into the Bodleian Library. Thus the history of the collection is complete. Formed by Dr. Thomas Brett, who died in 1743/4, it passed to his son Nicholas, who died in 1776. By the will of Nicholas Brett it passed to John Bowdler, who died in 1823; from him it descended to his son Thomas, who died in 1856. On his death-bed Mr. Bowdler gave the MSS. to Mr. Copeland, on whose death in 1885 it passed to a nephew. In 1887 it came into the market and was bought by Messrs. Bull and Auvache, from whom in 1888 it passed to Mr. T. W. Jackson. At his death in 1914 it was bought by an Oxford bookseller, and finally was sold to the Bodleian Library in 1916. There it is to be hoped its wanderings are done. Already scholars have begun to work on the MSS.; some results of a study of them are to be seen in Mr. Skipton's article on Thomas Deacon in the Church Quarterly Review for January, 1921, and the Non-Juror scholar Mr. H. Broxap, of the University of Manchester (at whose service the collection was placed by the University of Oxford last year), will soon unfold the story told by the MSS. in a definitive work. It is no part of my purpose to forestall Mr. Broxap's book, but I have read enough of the Brett MSS. to know how exceedingly interesting is the story they tell. The collection appears to be complete save for the three MSS. from it sent by Mr. Bowdler in June, 1856, to enlighten Dr. P. Wynter; they remain separated from their fellows, in the Library at St. John's; and two letters from the collection which were among Mr. Copeland's papers have recently come into my own possession. But now at last the collection is accessible and no future student of the romantic and instructive history of the NonJurors will have to pursue that elusive phantom " the Bowdler MSS.," nor undertake the thankless and almost hopeless search for "the papers of Dr. Brett." S. L. OlLARD. 